\title{
Literature Review: Peran Telehealth sebagai Upaya Pencegahan Readmisi Pasien dengan Acute Miocard Infark
}

\section{Literature Review: The Role of Telehealth as Readmission Prevention Strategy in Patient With Acute Miocard Infarct}

\author{
Meri Afridayani $^{1}$, Lailya Khusna ${ }^{2}$, Khairati Siregar ${ }^{3}$, Anggi Lukman Wicaksana ${ }^{4}$ \\ Fakultas Kedokteran, Kesehatan Masyarakat, dan Keperawatan, Universitas Gadjah Mada Yogyakarta, \\ Indonesia
}

\section{ARTICLE INFO}

\section{Article history}

Received date 06 Nov 2020

Revised date 18 Nov 2020

Accepted date 23 Nov 2020

Keywords:

Acute myocardial infarction; Relapse; Readmission;

Telehealth.

Kata kunci:

Akut miokardial infark; Kekambuhan;

Readmisi;

Telehealth.

\section{ABSTRACT/ ABSTRAK}

\begin{abstract}
Telehealth is an endeavor to prevent readmission in patients with Acute Miocard Infarct (AMI). The objective of this study was to identify the effect of Telehealth as a reoccurrence and readmission strategy for a patient with AMI. This study was a literature review with article searches in some databases including ScienceDirect, Sage Journals, Ebsco, Scopus, and Cochrane for the last ten years. The selected articles were limited to those in English with free full text. Studies that were involving adult AMI in the adult patient and obtaining intervention or monitoring via phone or Telehealth were included. The result from reviewed articles showed that Telehealth can be used as an alternative intervention to prevent readmission in patients with AMI. Various methods which are explained in the literature can be implemented as a strategy to prevent reoccurrence or readmission for the patient with AMI.
\end{abstract}

\begin{abstract}
Telehealth merupakan upaya pencegahan terjadinya readmisi pada pasien dengan akut miokardial infark (AMI) yang menjadi isu terkini. Tujuan dalam penelitian ini yaitu untuk mengetahui pengaruh telehealth terhadap strategi pencegahan kekambuhan dan readmisi pada pasien dengan AMI. Penelitian ini berupa literatur review dengan pencarian artikel dibeberapa database seperti Sciencedirect, Sage Journals, EBSCO, Scopus dan Cochrane dengan kriteria inklusi adalah acute myocardial infarction pada orang dewasa, yang mendapatkan intervensi atau monitoring via telepon, atau telehealth, jurnal berbahasa inggris dan batasan waktu kurang dari 10 tahun, serta free full text. Hasil dari semua artikel menyatakan bahwa intervensi Telehealth dapat digunakan sebagai alternatif intervensi untuk mencegah readmisi pada pasien dengan AMI. Upaya yang terdapat dalam literatur dapat digunakan sebagai strategi dalam mencegah kekambuhan atau readmisi pada pasien dengan AMI.
\end{abstract}

Corresponding Author:

Anggi L. Wicaksana

Fakultas Kedokteran, Kesehatan Masyarakat, dan Keperawatan, Universitas Gadjah Mada Yogyakarta, Indonesia Email: anggi.l.wicaksana@ugm.ac.id

\section{PENDAHULUAN}

Acute myocard infarction (AMI) merupakan salah satu jenis penyakit kardiovaskular. Didefinisikan sebagai suatu masalah yang terjadi pada otot jantung yang diakibatkan supply and demand oksigen ke dalam otot jantung berkurang sehingga kemampuan pompa oksigen menjadi berkurang atau kejadian nekrosis miokard yang disebabkan oleh unstable ischemic syndrome (Anderson \& Marrow, 2017). Gejala yang sering muncul adalah nyeri pada 
daerah dada menjalar ke punggung seperti tertimpa benda (retrosternal pain), sesak serta berkeringat dingin (Hannan, et al., 2011). Sedangkan konsumsi makanan yang berkolesterol merupakan faktor resiko paling tinggi diantara yang lainnya (Saktiningtyastuti \& Astuti, 2017).

Resiko kekambuhan pada AMI meskipun setelah melakukan Percutaneus Cardiac Intervention masih menduduki 2 tertinggi setelah ischemic heart disease, yakni 414 angka kejadian. Menurut ICD, hal ini diiakibatkan oleh komplikasi prosedur, seperti sumbatan, perdarahan, nefropati yang disebabkan oleh zat contrast, alur jenjang perawatan yang rumit dan sebagainya (Curtis, et al., 2009).

Tahun 2012, sebanyak $30 \%$ kematian di dunia disebabkan oleh penyakit kardiovaskular.Dengan perbandingan sebanyak $80 \%$ terjadi di Negara ekonomi menengah dan rendah. Non modifiable factor yang memengaruhi kejadian penyakit kardiovaskular antara lain, umur jenis kelamin, etnis dan riwayat keluarga. Sedangkan, modifiable factor seperti merokok, dyslipidemia, hipertensi, obesitas abdomen, ketidakdekuatan aktifitas fisik, faktor psychososial dan pola makan tidak seimbang menjadi faktor rsiko global terjadinya AMI (Gandhi, et al., 2017).

Berdasarkan data di atas, strategi pencegahan yang ditujukan untuk menurunkan angka kejadian mortalitas maupun menekan angka kejadian kekambuhan sangat diperlukan. Pemberian farmakoterapi sesuai indikasi dan modifikasi gaya hidup makin marak digalakkan oleh sejumah elemen masyarakat. Dengan demikian, selain angka mortalitas maupun morbiditas yang dapat ditekan, peningkatan status fungsi dan kualitas hidup bagi penderita penyakit kardiovaskular dapat ditingkatkan (Mols, Hald, Lomborg, \& Maeng, 2019).

Terdapat beberapa hambatan yang dihadapi oleh sebagian besar elemen kesehatan dalam tahap implementasi preventif AMI, antara lain sistem kesehatan yang belum memadai, faktor komunitas maupun faktor individu. Mengubah gaya hidup dan mematuhi regimen terapi yang telah diberikan menjadi kesulitan tersendiri bagi setiaip individu (Hannan, et al., 2011).

Teknologi Mobile health (mHealth) atau yang dikenal dengan telehealth merupakan suatu terobosan yang kini marak diperbincangkan, yang diharapkan mampu meningkatkan efektivitas pencegahan terhadap beberapa masalah kardiovaskuler. Didefinisikan sebagai suatu perangkat yang didukung dengan teknologi terkini, berisi konten kesehatan dan pelayanan kesehatan. Tahun 2018, hampir $50 \%$ penduduk global telah menggunakan smartphone. Oleh karena itu, terobosan terkini pada lini kesehatan telah sampai pada taraf penggunaan mobile device untuk pertukaran infomasi kesehatan, meningkatkan taraf kesehatan berbasis komunitas dengan menekan hambatan yang selama ini terjadi dan memotivasi perubahan gaya hidup. Selain itu, telehealth juga dapat menghemat biaya dengan probabilitas tinggi selama masa intervensi (Dixon, et al., 2016) dan diyakini mampu untuk melihat banyak faktor resiko yang saat ini terjadi (Klimis, Thakkar, Medicine, \& Chow, 2018). Sehingga, tujuan akhir dari sebuah tindakan preventif adalah menekan berbagai macam faktor resiko yang dapat mengakibatkan peningkatan angka kejadian AMI, pencegahan kekambuhan, dan follow up pasca hospitalisasi.

Penulisan literature review ini ditulis secara sinsematis. Penggunaan PRISMA 2009 (gambar 1) untuk melakukan transparansi dan kejelasan artikel yang digunakan dan memberikan panduan yang jelas tentang bagaimana melakukan tinjauan sistematis. Kata kunci yang digunakan yaitu "acute myocardial infarction" OR "acute myocardial infarcts" OR ami AND "nursing telehealth" OR "telehealth" OR "telemedicine" OR "telephone" OR "mobile phone" OR "telephone And Follow up" AND "relapse after treatment" $O R$ "self management" OR "readmission".

Hasil dari semua pencarian database mengasilkan 814.592 artikel, dengan menyaring batasan waktu kurang dari 10 tahun (2010-2019), free full text, bahasa inggris, menghasilkan 2941 artikel, penyaringan selanjutnya menggunakan judul yang tidak sesuai dengan pertanyaan penelitian tersisa 12 artikel, abstrak tidak terfokus tersisa 4 artkel, artikel tidak secara jelas memberikan solusi terkait intervensi atau monitoring via telepon, telehealth, dan atau telemedicine, tersisa 3 artikel. Lalu dilakukan critical appraisal dengan menggunakan tool dari Joanna Briggs Institute dan menilai risk of bias dengan menggunakan tool dari Cochrane.

Hasil dari risk of bias (gambar 2) pada artikel ini yaitu berada pada kategori risiko rendah dimana pada empat kategori menunjukkan resiko yang sangat rendah (100\%), sedangkan untuk resiko tinggi hanya ditunjukkan pada 1 kategori dan tidak melebih dari $50 \%$ dari nilai keseluruhan. 


\section{PEMBAHASAN}

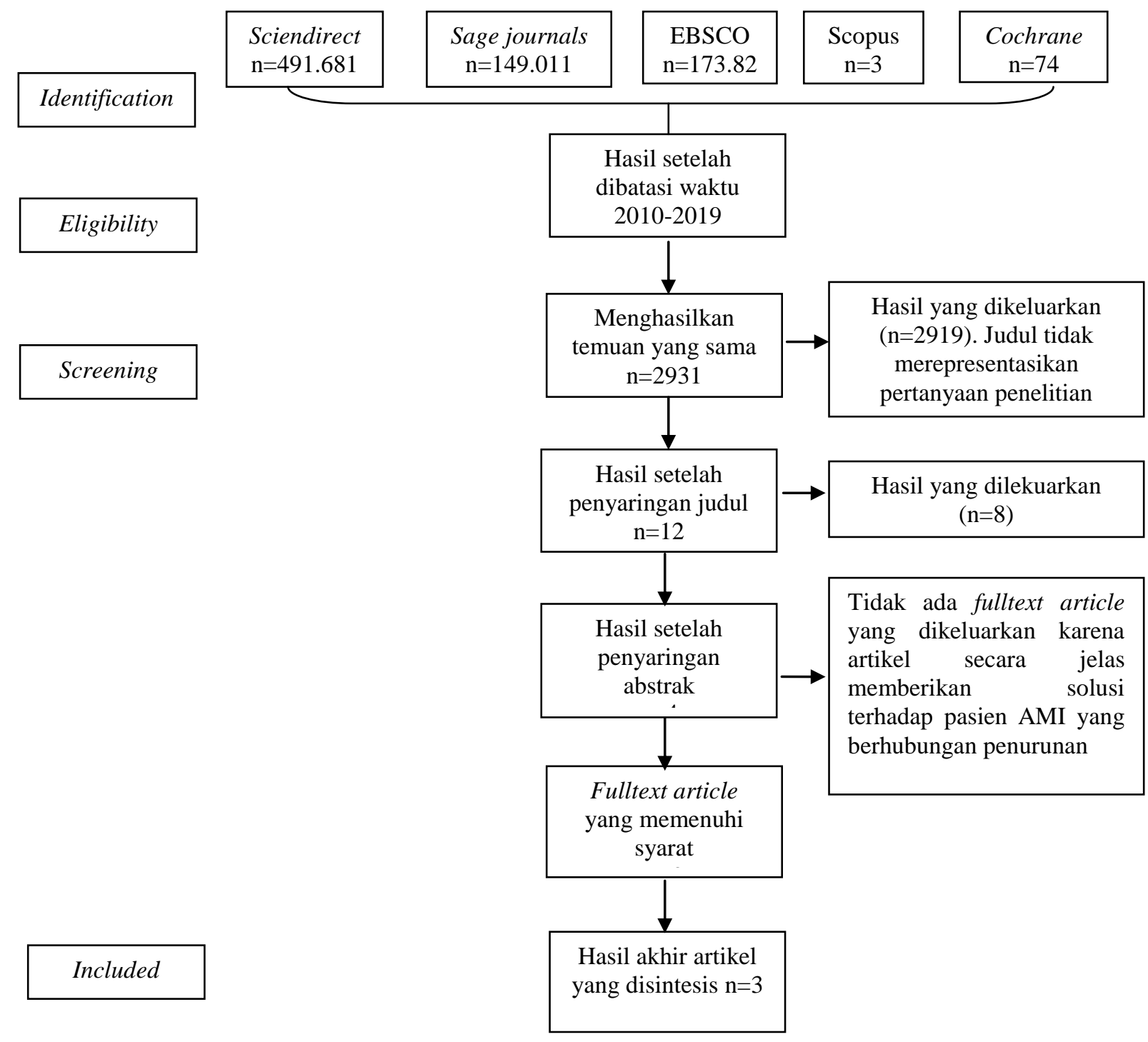

Gambar 1. Bagan PRISMA pencarian 
Tabel 1. Sintesis Analisis

\begin{tabular}{|c|c|c|c|c|}
\hline $\begin{array}{c}\text { Peneliti/ } \\
\text { tahun }\end{array}$ & Judul & $\begin{array}{c}\text { Metode } \\
\text { penelitian }\end{array}$ & Hasil penelitian & Keterbatasan \\
\hline $\begin{array}{l}\text { Jin, et } \\
\text { al.,(2019) }\end{array}$ & $\begin{array}{l}\text { Telehealth } \\
\text { interventions } \\
\text { for the } \\
\text { secondary } \\
\text { prevention of } \\
\text { coronary } \\
\text { heart disease: } \\
\text { A systematic } \\
\text { review and } \\
\text { meta-analysis }\end{array}$ & $\begin{array}{l}\text { Systematic } \\
\text { Review }\end{array}$ & $\begin{array}{l}\text { Hasil pencarian literatur dengan } \\
\text { mengidentifikasi } 14.289 \text { artikel didapatkan } \\
29 \text { artikel RCT. } \\
\text { Dengan melakukan intervensi menggunakan } \\
\text { telehealth dapat menurunkan resiko pada } \\
\text { pasien dengan PJK dan menurunkan angka } \\
\text { readmisi, seperti: } \\
\text { 1. Total cholesterol (TC) dari } 16 \text { trials } \\
\text { artikel, dalam follow-up selama } 3-48 \\
\text { bulan, dapat menurunkan dengan } \\
\text { perbedaan rerata } 0,26 \text { mmol/l. } \\
\text { 2DL dari } 12 \text { trials artikel, dengan } \\
\text { follow-up selama } 3-48 \text { bulan dapat turun } \\
\text { dengan perbedaan rerata } 0,28 \text { mmol/l. } \\
\text { 3. Smoking dari } 8 \text { trials artikel, follow-up } \\
\text { selama 3-48 bulan terjadi sekitar } 23 \% \\
\text { pengurangan merokok. } \\
\text { 4. Physical activity dari } 6 \text { trials artikel, } \\
\text { dapat meningkatkan level dari aktivitas } \\
\text { fisik. } \\
\text { 5sychosocial dari } 10 \text { trials artikel, } \\
\text { meningkatkan status psikososial pasien. } \\
\text { 6. Menurunkan biaya untuk perawatan. }\end{array}$ & $\begin{array}{l}\text { Dalam artikel ini, semua artikel } \\
\text { tidak dilakukan blinding baik } \\
\text { pada partisipan maupun pada } \\
\text { pemberi intervensi sehingga dapat } \\
\text { menyebabkan terjadinya resiko } \\
\text { bias. }\end{array}$ \\
\hline $\begin{array}{l}\text { Kirchberger } \\
\text {, Hunger, } \\
\text { Stollenwerk } \\
\text { \& Seidl, } \\
\text { (2015) }\end{array}$ & $\begin{array}{l}\text { Effects of a 3- } \\
\text { Year Nurse- } \\
\text { Based Case } \\
\text { Management } \\
\text { in Aged } \\
\text { Patients with } \\
\text { Acute } \\
\text { Myocardial } \\
\text { Infarction on } \\
\text { Rehospitalisat } \\
\text { ion, Mortality, } \\
\text { Risk Factors, } \\
\text { Physical } \\
\text { Functioning } \\
\text { and Mental } \\
\text { Health. A } \\
\text { Secondary } \\
\text { Analysis of } \\
\text { the } \\
\text { Randomized } \\
\text { Controlled } \\
\text { KORINNA } \\
\text { Study }\end{array}$ & $\mathrm{RCT}$ & $\begin{array}{l}\text { Penelitian dilakukan antara September } \\
\text { 2011-mei 2013, dengan total sampel } 340 \\
\text { sampel yang dibagi dalam } 2 \text { kelompok } \\
\text { yaitu case-management } 161 \text { sampel dan } \\
\text { usual care } 168 \text { sampel. } \\
\text { Penilaian ini dilakukan pada bulan ke } 12 \\
\text { dan bulan ke-36. Dimana pengukuran } \\
\text { untuk hasil menggunakan The Health } \\
\text { Assessment Questionnaire Disability } \\
\text { Index (HAQ-DI),/ the Instrumental } \\
\text { Activities of Daily Life Scale (IADL), } \\
\text { questionnaire SCREEN-II (Seniors in the } \\
\text { Community: Risk evaluation for eating } \\
\text { Adapun hasil akhir dari penelitian ini } \\
\text { yaitu bahwa telehealth efektif } \\
\text { menurunkan readmisi. }\end{array}$ & $\begin{array}{l}\text { Pada awalnya peneliti ingin } \\
\text { melakukan double blind untuk } \\
\text { mencegah terjadinya bias. Akan } \\
\text { tetapi hal itu tidak susah } \\
\text { dilakukan bila perawat melakukan } \\
\text { visitasi pasti akan mengetahui } \\
\text { apakah ini kelompok control. Dan } \\
\text { akhirnya penliti memakai single } \\
\text { blind yaitu untuk pengambil data } \\
\text { blind terhadap pasien tersebut. }\end{array}$ \\
\hline $\begin{array}{l}\text { Leemrijse, } \\
\text { et al., } \\
(2016)\end{array}$ & $\begin{array}{l}\text { The telephone } \\
\text { lifestyle } \\
\text { intervention } \\
\text { 'Hartcoach' } \\
\text { has modest } \\
\text { impact on } \\
\text { coronary risk } \\
\text { factors: A } \\
\text { randomised } \\
\text { multicentre } \\
\text { trial }\end{array}$ & RCT & $\begin{array}{l}\text { Hartcoach dilakukan selama } 6 \text { bulan, } \\
\text { dimana pelatih yang ditugaskan } \\
\text { melakukan komunikasi dengan pasien } \\
\text { setiap 4-6 minggu sekali melalui telepon. } \\
\text { Setiap sesi membutuhkan waktu 20-30 } \\
\text { menit dan sudah termasuk dengan } \\
\text { perjanjian pada telepon berikutnya. } \\
\text { Hasil dalam penelitian yaitu Harcoach } \\
\text { dapat menurunkan jumlah skor resiko } \\
\text { sesuai target: } \\
\text { 1. BMI } \\
\text { 2. Lingkar pinggang } \\
\text { 3. Aktivitas fisik } \\
\text { 4. Asupan sayuran harian } \\
\text { 5. Pengelolaan diri } \\
6 . \text { Kesemasan }\end{array}$ & $\begin{array}{l}\text { - Pasien yang mendapatkan } \\
\text { pendampingan (coaching) dapat } \\
\text { memiliki kecenderungan } \\
\text { melaporkan yang lebih positif. } \\
\text { - Penggunaan food quesionaire } \\
\text { untuk mengukur lemak jenuh, } \\
\text { tidak dapat dilakukan secara } \\
\text { terpisah dengan lemak total, } \\
\text { mengakibatkan kesulitan didalam } \\
\text { proses analisa, apakah pasien } \\
\text { benar-benar mencapai skor target } \\
\text { pada faktor resiko atau tidak. } \\
\text { - Lebih dari 97\% partisipan } \\
\text { mendapatkan skor yang cukup } \\
\text { tinggi pada kuesioner kepatuhan } \\
\text { pengobatan dan distribusi skor } \\
\text { yang dihasilkan cenderung } \\
\text { berbeda dengan kelompok } \\
\text { kontrol. }\end{array}$ \\
\hline
\end{tabular}


Tabel 2. Karakterisktik Risk of Bias

\begin{tabular}{|c|c|c|c|}
\hline Criteria & Kirchberger, et al., (2015) & Leemrijse, et al., (2016) & Jin. et al., (2019) \\
\hline $\begin{array}{l}\text { Random } \\
\text { sequence } \\
\text { generation }\end{array}$ & $\begin{array}{l}\text { 'Low risk of bias (dengan } \\
\text { menggunakan randomized blocks } \\
\text { within strata for sex, age (<70 vs. } \\
70-79 \text { vs. } 80+\text { years) and number } \\
\text { of comorbidities (diabetes and } \\
\text { chronic heart failure) } \\
+\end{array}$ & $\begin{array}{l}\text { Low risk of bias. } \\
\text { Penggunaan sample random } \\
\text { allocation dalam penentuan } \\
\text { partisipan penelitian. }\end{array}$ & $\begin{array}{l}\text { Low risk of bias. } \\
75 \% \text { dari hasil } \\
\text { analisis kasus } \\
\text { menyatakan Low risk } \\
\text { of bias. } \\
+\end{array}$ \\
\hline $\begin{array}{l}\text { Allocation } \\
\text { concealment }\end{array}$ & $\begin{array}{l}\text { Low risk of bias (Central allocation } \\
\text { by biostatistical center of the } \\
\text { Helmholtz Zentrum München). }\end{array}$ & $\begin{array}{l}\text { Low risk of bias. } \\
\text { Informasi tertulis yang berisi } \\
\text { informasi kode pasien } \\
\text { tercatat didalam NIVEL } \\
\text { research } \\
\text { Concealment center. } \\
\text { penelitian ini tidak teresebut } \\
\text { secara jelas. }\end{array}$ & $\begin{array}{l}\text { Unclear risk of bias. } \\
\text { Yaitu lebih dari } 50 \% \\
\text { artikel yang telah di } \\
\text { analisis }\end{array}$ \\
\hline $\begin{array}{l}\text { Blinding of } \\
\text { participants } \\
\text { and personnel }\end{array}$ & $\begin{array}{l}\text { Low risk of bias (Tidak ada } \\
\text { blinding atau blinding tidak } \\
\text { lengkap, tetapi peneliti review } \\
\text { menilai bahwa hasilnya tidak akan }\end{array}$ & $\begin{array}{l}\text { Low risk of bias. } \\
\text { Blinding dilakukan oleh } \\
\text { research nurses and } \\
\text { cardiologist. }\end{array}$ & $\begin{array}{l}\text { High risk of bias. } \\
\text { Yaitu } 100 \% \text { dari } \\
\text { semua artikel yang di } \\
\text { analisis }\end{array}$ \\
\hline
\end{tabular}
dipengaruhi oleh kurangnya blinding).

\begin{tabular}{llllll} 
& & & & \\
\hline Blinding of & Low risk bias (orang yang & Low risk of bias & & Low risk of bias \\
outcome & melakukan penilaian hasil 1 dan 3 & Tidak dijelaskan didalam & Yaitu 50\% dari \\
Assessment & tahun dan orang yang memvalidasi & analisa outcome & hasil & semua atikel
\end{tabular}
tidak terlibat dalam pemberian intervensi dan mengetahui apakah termasuk ke dalam blind terhadap kelompok control maupun intervensi).

\begin{tabular}{ll} 
& + \\
\hline Incomplete & Low risk bias. Untuk data hasil \\
outcome data & yang berkelanjutan, ukuran efek \\
& yang masuk akal (perbedaan rata- \\
& rata atau perbedaan standar dalam \\
& rata-rata) di antara hasil yang hilang \\
& tidak cukup untuk memiliki dampak \\
& yang relevan secara klinis pada \\
& ukuran efek yang diamati.
\end{tabular}




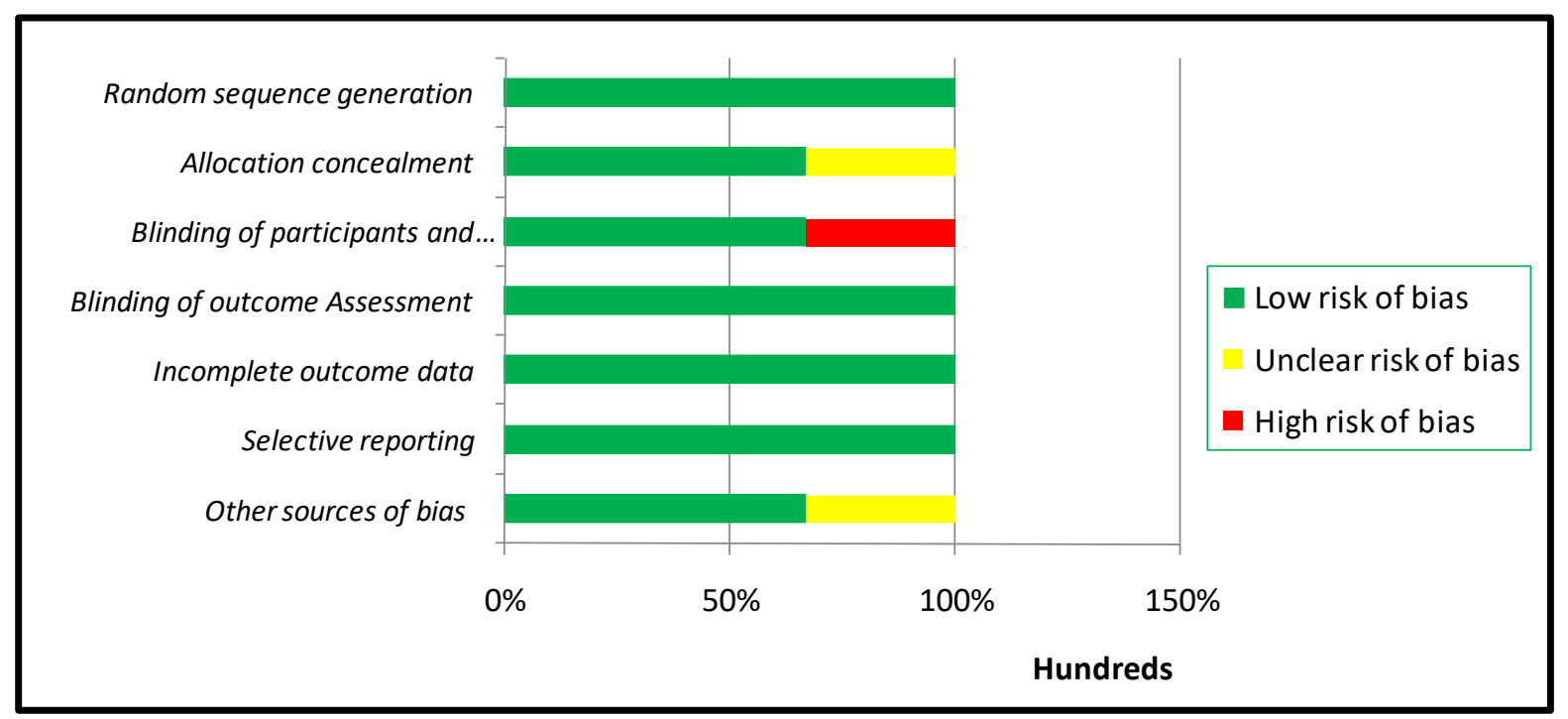

Gambar 2. Grafik Karakterisktik risk of bias

Telehealth atau Telemedicine (TM) adalah penggunaan sistem telekomunikasi untuk memberikan perawatan kesehatan dari jauh. Yang memiliki potensi untuk meningkatkan hasil kesehatan pasien, akses ke perawatan kesehatan (Flodgren, et al, 2015) dan mengurangi biaya perawatan kesehatan (Whittaker \& Wade, 2014). Telehealth juga bisa digunakan sebagai alternatif, atau sebagai tambahan, perawatan biasa yaitu melalui konsultasi dengan tatap muka.

Pada penyakit jantung, Telehealth interventions terbukti bisa digunakan sebagai salah satu jenis perawatan yang dapat ditawarkan kepada pasien sebagai secondary prevention. Penelitian yang dilakukan oleh Kirchberger, et al. (Kirchberger, Hunger, Stollenwerk, Seidl, et al., 2015) menggunakan tiga buah kuisioner yang berbeda untuk melihat efek dari Telehealth interventions yaitu The Health Assessment Questionnaire Disability Index (HAQ-DI), the Instrumental Activities of Daily Life Scale (IADL), questionnaire SCREEN-II (Seniors in the Community: Risk evaluation for eating and nutrition, Version II). Hasil pada pengukuran pertama 12 bulan setelah intervensi diperoleh bahwa Telehealth interventions dapat menurunkan angka readmission, mortality pada pasien infark miokard. Pada pengukuran kedua yang dilakukan 36 bulan setelah perawatan, hasil tidak begitu menunjukkan perbedaan yang signifikan dibandingkan pada pegukuran pertama baik pada kelompok kontrol maupun intervensi dalam hal kejadian angka readmisi, mortality, dan kekuatan fisik, akan tetapi pada status gizi terjadi peningkatan hasil yang signifikan.

Penelitian Leemrijse, et al. (2016) yang menggunakan program intervensi telehealth Hartcoach, yaitu suatu program yang berfungsi untuk mengatur gaya hidup pasien dengan penyakit kardiovaskular disertai dengan monitoring proses yang terjadi melalui telepon yang dilaksanakan oleh perawat terlatih. Perawat disini bertugas untuk menggali informasi tentang faktor risiko individu dan target yang tepat; mengkaji tentang metode yang tepat untuk mencapai target pada faktor risiko; kemudian menegosiasikan rencana untuk mencapai target tersebut; memberikan pandangan yang dapat merangsang seseorang untuk diet sehatdan perilaku olahraga; memberikan pemantauan dan umpan balik terhadap kemajuan yang terjadi; menekankan kepada pasien tentang tanggung jawab pada diri sendiri; dan pentingnya bekerjasama dengan penyedia layanan kesehatan dan lingkungan terkait dengan melakukan kontrol ulang ke rumah sakit untuk pemeriksaan laboratorium.

Enam bulan setelah intervensi Hartcoach telehealth ini menunjukkan hasil yang significant terhadap hasil indeks massa tubuh (BMI), lingkar pinggang, aktivitas fisik, asupan sayuran setiap hari, pengelolaan sendiri, dan kecemasan. Pada penelitian ini juga diketahui bahwa Hartcoach dapat menjadi program untuk meningkatkan manajemen diri dan mengurangi faktor risiko.terhadap penyakit jantung koroner.

Hasil yang sama juga ditunjukkan dari penelitian yang dilakukan oleh Huber, et al. (2017) dengan menggunakan ACS NAILED (Nurse-based Age-independent Intervention to Limit Evolution of Disease after Acute Coronary Syndrome). Follow up dengan menggunakan berbasis telepon yang dipimpin oleh perawat, adapun materi konseling yang dilakukan intervensi ini yaitu mengenai titrasi terhadap obat-obatan yang diberikan dan gaya hidup 
pasien setelah keluar dari rumah sakit. Pada kelompok intervensi diperoleh hasil yang significat dalam peningkatan terhadap terget LDL-C $(<2,5 \mathrm{mmol} / \mathrm{L})$ dan tekanan darah (BP; $<140 / 90 \mathrm{mmHg}$ ) dibandingkan perawatan biasa (kelompok kontrol).

Jin, et al. (2019) dalam penelitiannya menyebutkan bahwa Telehealth tidak memberikan perbedaan yang signifikan terhadap angka kematian dibanding dengan rehabilitasi jantung dan/atau perawatan biasa. Akan tetapi Telehealth secara bermakna dikaitkan dengan rendahnya readmission atau kejadian serangan jantung berulang dibandingkan dengan kelompok non-intervensi. Kegagalan dalam pencegahan penyakit jantung sekunder sering disebabkan oleh ketidakkepatuhan pasien dalam melakukan saran pengobatan yang telah disampaikan sebelumnya oleh dokter maupun perawat. Hasil yang sama juga disebutkan oleh Adler, et al, (2017) dalam penelitiannya yang menyebutkan bahwa dengan melakukan mobile phone text dapat meningkatkan kepatuhan pasien dalam kepatuhan terhadap obat-obatan untuk pencegahan sekunder penyakit jantung khususnya apabila dilakukan di negara khususnya berpenghasilan rendah dan menengah.

Secara keseluruhan, penilaian kualitas risiko bias untuk ketiga studi menunjukkan dominasi pada risiko rendah. Hal ini menunjukkan bahwa kualitas artikel yang dilakukan telaah berada pada kualitas yang baik. Risiko bias yang tinggi hanya dijumpai pada bagian blinding of participants and personnel". Pada penelitian dengan menggunakan Telehealth, proses blinding bisa jadi sulit dilakukan karena partisipan terlibat secara langsung dan menerapkan untuk mengatasi keluhan yang dirasakan.

\section{SIMPULAN}

Telehealth atau Telemedicine (TM) adalah penggunaan sistem telekomunikasi untuk memberikan perawatan kesehatan dari jauh yang memiliki potensi untuk meningkatkan hasil kesehatan pasien, akses ke perawatan kesehatan dan mengurangi biaya perawatan kesehatan. Intervensi telehealth memiliki berbagai cara dalam proses penyampaiannya bisa melalui pesan ataupun telepon sehingga intervensi ini bisa diberikan kepada pasien yang tidak dapat menghadiri rehabilitasi jantung secara langsung atupun konsultasi dengan tatap muka.

Selain itu Telehealth sendiri terbukti sebagai pencegahan sekunder yang efektif untuk mencegah terjadinya serangan jantung berulang dengan menurunkan faktor-faktor resiko yang dapat meningkatkan kejadian serangan berulang pada pasien dengan gangguan jantung dan memperkuat hasil dari program rehabilitasi jantung dibandingkan dengan intervensi rehabilitasi yang biasa dilakukan pada pasien jantung, dengan kombinasi atau intervensi tambahan Telehealth atau Telemedicine angka readmisi dapat diturunkan secara signifikan. Dengan melakukan pencegahan sekunder setelah sindrom koroner akut (ACS) dapat mengurangi angka morbiditas dan kematian.

Melihat hasil yang cukup baik, perlu pengaplikasian atau penerapan teleHealth ini di Indonesia, dengan sebelumnya perlu untuk menganalisis kemungkinan hambatan, kriteria kompetensi perawat dan pelaksana yang harus dimiliki dan dipersiapkan dalam strategi perencanaan. Program telehealth intervention perlu dilakukan secara rutin untuk melihat kepatuhan pasien terhadap pengobatan dan memonitor pasien dalam mengubah perilaku untuk hidup sehat, sehingga perlu dilakukan evaluasi secara berkala untuk melihat kemajuan dari program yang telah dillaksanakan.

\section{DAFTAR PUSTAKA}

Adler, A., Martin, N., Mariani, J., Cd, T., Oo, O., Free, C., ... Perel, P. (2017). Mobile phone text messaging to improve medication adherence in secondary prevention of cardiovascular disease ( Review ) SUMMARY OF FINDINGS FOR THE MAIN COMPARISON. Cochrane Database Syst Rev, (4). https://doi.org/10.1002/14651858.CD0118 51.pub2.www.cochranelibrary.com
Anderson, J. L., \& Marrow, D. (2017). Acute Myocardial Infarction. The NEW ENGLAND JOURNAL of MEDICINE, 2053-2064. https://doi.org/10.1056/NEJMra1606915

Curtis, J. P., Schreiner, G., Wang, Y., Spertus, J. A., Rumsfeld, J. S., Brindis, R. G., \& Krumholz, H. M. (2009). All-Cause Readmission and Repeat Revascularization After Percutaneous Coronary Intervention 
in a Cohort of Medicare Patients. JAC, 54(10), 903-907. https://doi.org/10.1016/j.jacc.2009.04.076

Dixon, P., Hollinghurst, S., Ara, R., Edwards, L., Foster, A., \& Salisbury, C. (2016). Costeffectiveness modelling of telehealth for patients with raised cardiovascular disease risk: evidence from a cohort simulation conducted alongside the Healthlines randomised controlled trial. BMJ Open, 18. https://doi.org/10.1136/bmjopen-2016012355

Flodgren, G., Rachas, A., Farmer, A. J., Inzitari, M., \& Shepperd, S. (2015). Interactive telemedicine: effects on professional practice and health care outcomes SO-: Cochrane Database of Systematic Reviews YR-: 2015 NO-: 9. Cochrane Database of Systematic Reviews Interactive, Art. No.:(9), $1-583$. https://doi.org/10.1002/14651858.CD0020 98.pub2.www.cochranelibrary.com

Gandhi, S., Chen, S., Hong, L., Sun, K., Gong, E., Li, C., ... Schwalm, J. (2017). Systematic Review / Meta-analysis Effect of Mobile Health Interventions on the Secondary Prevention of Cardiovascular Disease: Systematic Review and Metaanalysis. Canadian Journal of Cardiology, 33(2),

219-231. https://doi.org/10.1016/j.cjca.2016.08.017

Hannan, E. L., Zhong, Y., Krumholz, H., Walford, G., Holmes, D. R., Stamato, N. J., ‥ Iii, B. K. (2011). 30-Day Readmission for Patients Undergoing Percutaneous Coronary Interventions in New York State. JCIN, 4(12), 1335-1342. https://doi.org/10.1016/j.jcin.2011.08.013

Huber, D., Henrikssom, R., Jakobsson, S., \& Mooe, T. (2017). Nurse-Led TelephoneBased Follow-up of Secindary Prevention After Acute Coronary Syndrome: OneYear Results from the Randomized Controlled NAILED-ACS Trial.

Jin, K., Khonsari, S., Gallagher, R., Gallagher, P., Clark, A. M., Freedman, B., ... Neubeck, L. (2019). Telehealth interventions for the secondary prevention of coronary heart disease: A systematic review and meta- analysis. European Journal of Cardiovascular Nursing, 18, 260-271. https://doi.org/10.1177/1474515119826510

Kirchberger, I., Hunger, M., Stollenwerk, B., \& Seidl, H. (2015). Effects of a 3-Year Nurse-Based Case Management in Aged Patients with Acute Myocardial Infarction on Rehospitalisation , Mortality , Risk Factors, Physical Functioning and Mental Health. A Secondary Analysis of the Randomized Controlled KORINNA Study. PLoS ONE, 1-17. https://doi.org/10.1371/journal.pone.0116693

Klimis, H., Thakkar, J., Medicine, I., \& Chow, C. K. (2018). Breaking Barriers: Mobile Health Interventions for Cardiovascular Disease. Canadian Journal of Cardiology, 34(7), 905-913. https://doi.org/10.1016/j.cjca.2018.02.012

Leemrijse, C. J., Peters, R. J. G., Birgelen, C. Von, Dijk, L. Van, Hal, J. M. C. Van, Kuijper, A. F. M., ... Veenhof, C. (2016). The telephone lifestyle intervention " Hartcoach " has modest impact on coronary risk factors: A randomised multicentre trial. European Journal of Preventive Cardiology, 23(15), 1658-1668. https://doi.org/10.1177/2047487316639681

Mols, R. E., Hald, M., Lomborg, K., \& Maeng, M. (2019). Nurse-led Motivational Telephone Follow-up After Same-day Percutaneous Coronary Intervention Reduces Readmission and Contacts to General Practice, 34(3), 222-230. https://doi.org/10.1097/JCN.00000000000 00566

Saktiningtyastuti, F., \& Astuti, S. L. D. (2017). Faktor Yang Mempengaruhi Serangan Jantung Berulang Pada Pasien Ami Di Ruang Icvcu Rsud Dr. Moewardi Tahun 2016 Fransisca Saktiningtyastuti, Sri Lestari Dwi Astuti. Junal Keperawatan Global, 2(1), 35-45.

Whittaker, F., \& Wade, V. (2014). The Costs and Benefit of Technology-enables, HomeBased Cardiac rehabilitation Measured in a Randomised Controlled Trial. Journal of Telemedicine and Telecare, 20, 419-422. https://doi.org/10.1177/1357633X14552376 